\title{
A STRESSZ SZEREPE A SZOCIOÖKONÓMIAI HELYZET ÉS A VÉGREHAJTÓ MÚKÖDÉSEK KÖZÖTTI KAPCSOLAT SZEMPONTJÁBÓL GYERMEKKORBAN
}

\author{
KASSAI RÉKA ${ }^{1 *}$ - FUTÓ JUDIT ${ }^{2}$ - TAKÁCS ZSÓFIA K. ${ }^{3}$ \\ ${ }^{1}$ Eötvös Loránd Tudományegyetem, Pszichológia Doktori Iskola, Budapest, Magyarország \\ MTA-ELTE Lendület Adaptáció Kutatócsoport \\ ${ }^{2}$ Eötvös Loránd Tudományegyetem, Pszichológiai Intézet, Budapest, Magyarország \\ ${ }^{3}$ School of Health in Social Science, University of Edinburgh, Edinburgh, Skócia, \\ Egyesült Királyság \\ E-mail: kassai.reka@ppk.elte.hu
}

Benyújtva: 2020. december 29. - Elfogadva: 2021. április 30.

Háttér és célkitúzések: A szocioökonómiai szempontból hátrányos helyzetben felnövố gyermekek az élet számos területén, köztük az olyan kognitív készségek fejlódésében is, mint a végrehajtó funkciók mutatnak elmaradást a magasabb társadalmi osztályú családok gyermekeihez képest. Feltételezhetố, hogy ezen jelenség hátterében álló egyik mechanizmus az, hogy ezek a gyermekek fokozottabb káros stresszhatásoknak vannak kitéve az életük során. Jelen tanulmány célja az volt, hogy magyarországi mintán tanulmányozzuk a szocioökonómiai helyzet egyes komponenseinek és a végrehajtó funkcióknak a kapcsolatát óvodás korú gyermekek esetében, illetve a kortizolhormonszint (mint a stressz indikátora) ezen kapcsolatban játszott szerepét.

Módszer: A kutatás során négy különböző óvodából toboroztunk szocioökonómiai szempontból heterogén mintát. Az elemzéseket 76 résztvevố (45 fiú, 31 lány, életkoruk 52-83 hó, átlag életkoruk 70,85 hó) adatai alapján végeztük: A szocioökonómiai státuszra vonatkozó információkat szülóktốl gyüjtöttük kérdốves módszerrel, a gyerekek végrehajtó funkcióit számítógépen végzett neuropszichológiai tesztekkel (Corsi-kocka, Go/ No-Go, Hearts and Flowers) vizsgáltuk, a gyerekek stresszszintjére pedig a kortizolhormonszintjük (reggeli nyálminta, ELIZA-módszerrel történö elemzés) alapján következtettünk.

Eredmények: Az eredményeink összhangban vannak a korábbi szakirodalmak következtetéseivel, miszerint az általunk mért szocioökonómiai helyzet komponensei közül csak a szülôi iskolázottság mutat szignifikáns kapcsolatot a gyermek végrehajtó múködéseivel, a család bevétele nem. Továbbá a kortizolhormonszint részleges mediáló hatással van ezen változók kapcsolatára.

Következtetések: Megalapozottan feltételezhetjük tehát, hogy a fokozott stressz az egyik tényezö, amelyen keresztül a szocioökonómiai helyzet befolyással van a gyermekek kognitív készségeire, azonban további faktorok is meghatározóak lehetnek.

Kulcsszavak: szocioökonómiai helyzet, kortizol, végrehajtó funkciók, óvodáskor

${ }^{*}$ levelezố szerzô

(C) 2021 A szerzố(k) 


\section{BEVEZETÉS}

A szakirodalomban egyértelmú bizonyítékokat találunk arra vonatkozóan, hogy a gyermekek szocioökonómiai státusza (SES) összefügg a pszichológiai jóllétükkel (Duncan, Magnuson és Votruba-Drzal, 2017; Yoshikawa, Aber és Beardslee, 2012). Számos tudományos eredmény alátámasztotta már azt is, hogy a szegénység és aluliskolázottság sújtotta környezetben felnövố gyermekek fejlôdése mind kognitív, mind szociális-érzelmi szempontból elmarad a jobb körülmények között élố társaikétól (Lawson, Hook és Farah, 2018; Sarsour és mtsai, 2011). Az ezen jelenség hátterében álló komplex mechanizmusokról még bizonytalan a tudásunk, bár számos magyarázat és megközelítés létezik. Az eddigi kutatások alapján az egyik valószínúsíthetố potenciális háttérmechanizmus, amely meghatározó lehet, az a stressz (Duncan és mtsai, 2017), pontosabban a stresszes életeseményeknek való kitettség eltérô mértéke, illetve a stresszel való megküzdésre szolgáló készségek eltérô múködése (Evans, 2004; Evans és Kim, 2013).

Az alacsony szociális és társadalmi helyzetú családokban élố gyermekek és felnôttek életük során több stresszkeltố életeseménynek vannak kitéve, mint a közepes vagy magas társadalmi osztályhoz tartozók (Evans és English, 2002; Hatch és Dohrenwend, 2007). A gyermekek fokozott stressznek való kitettsége fakadhat a szúk családot érintố nehézségek által okozott frusztrációból. Ilyen például a szülôkre nehezedô gazdasági, anyagi nehézségek által okozott feszültség vagy a családon belüli konfliktusok, szociális támogatás hiánya (Evans és English, 2002), esetleg a családon belüli elhanyagolás vagy bántalmazás (Van IJzendoorn, Bakermans-Kranenburg, Coughlan és Reijman, 2020). Ezen stresszoroknak való kitettség nemcsak közvetlenül a gyermekre van káros hatással (Crnic, Gaze és Hoffman, 2005), hanem a szüló gyermeknevelési készségeit, erôforrásait is negatívan befolyásolhatja. A fokozott szülő́i stressz kevésbé stimuláló, és válaszkész gondozással jár együtt, ami a gyermek bizonytalan kötődését eredményezheti (Casady, Diener, Russell és Wright, 2001). Az alacsonyabb minôségú szülői gondoskodás és a nem biztonságos kötôdési mintázat pedig a gyermek fokozott pszichológiai stresszreaktivitásához vezet (Duncan és mtsai, 2017; Groh és Narayan, 2019).

A családon belüli interperszonális hatásokon kívül fontos figyelembe venni a környezet körülményeibốl fakadó stresszorokat is, amelyekben szintén nagyobb eséllyel válnak érintetté az alacsony szocioökonómiai helyzetû gyermekek (Evans és English, 2002). Ilyenek például a hátrányosabb fizikai környezeti feltételek, mint a rosszabb lakhatási körülmények, a háztartáson belüli zsúfoltság, magasabb háztartási rendezetlenség és zajszint (Casey és mtsai, 2017; Evans, 2004; Mills-Koonce és mtsai, 2016). A tágabb lakókörnyezet hatásai szintén idetartoznak, ilyen például, hogy nagyobb esélylyel élnek a hátrányos helyzetû gyermekek szegregátumban (Iceland és Hernandez, 2017), és/vagy olyan környéken, ahol az átlagosnál magasabb a búnelkövetések száma (Hsieh és Pugh, 1993). Ezeken a környékeken jellemzô, hogy az iskolák felszereltsége alacsonyabb szintú, ezek az intézmények gyakrabban küzdenek anyagi problémákkal, eszköz- vagy szakemberhiánnyal (Ercse, 2019; Owens és Candipan, 2019), továbbá nehezített lehet a megfelelố egészségügyi és szociális ellátáshoz, közszolgáltatásokhoz való hozzáférés is (Evans és Kim, 2013; Leventhal, 2018). Ezek hiánya értelemszerúen nem csökkenti, sốt akár hozzájárul a családon belüli interperszonális stresszorok hatásának kifejezôdéséhez, egyfajta ördögi kört hozva létre, amely által az alacsony szocio- 
ökonómiai helyzetben élố gyermek szinte minden életterületen a káros stresszhatások emelkedett szintjének van kitéve (Santiago, Wadsworth és Stump, 2011).

Az átélt pszichológiai vagy fiziológiai stressz egyik megbízható biológiai indikátora a mellékvese kéregállománya által termelt kortizolhormon szintje (McEwen, 2019). Számos kutatási eredmény számol be arról, hogy a gyakori káros stresszhatásoknak való kitettség emelkedett kortizolszintet (Stalder és mtsai, 2017), illetve megváltozott stresszreaktivitást eredményez (Fogelman és Canli, 2018). A nemzetközi szakirodalomban számos eredményrốl számolnak be, amelyekben a SES együtt járást mutat bizonyos kortizolmutatókkal, gyermek és felnôtt résztvevôk esetében egyaránt (Lupien, King, Meaney és McEwe, 2001; Wright és Steptoe, 2005).

A SES szintén széles körû vizsgálatok által alátámasztottan kapcsolatot mutat a kognitív készségekkel, azon belül is a végrehajtó funkciókkal (Lawson és mtsai, 2018). Ezen múködések pedig óvodáskorban igen meghatározóak az iskolaérettség, illetve a késóbbi iskolai sikeresség (Blair és Razza, 2007; Blair és Diamond, 2008), továbbá a pszichológiai jóllét szempontjából is (Moffitt, 2012), hiszen azon képességeink öszszességét jelentik, amelyek a szándékos és célvezérelt viselkedés tervezéséhez, szervezéséhez, és kivitelezéséhez szükségesek (Lezak, 1982). A végrehajtó múködéseknek többféle csoportosítása létezik. Jelen vizsgálatban Adele Diamond (2013) fejlôdésszempontú modellje alapján három komponenst különböztetünk meg: a munkamemóriát, a gátlást és a kognitív flexibilitást. A munkamemória teszi lehetôvé, hogy egyszerre többféle - vizuális vagy verbális - információt észben tartsunk, és ezekkel múveleteket végezzünk, például kiemeljük a lényegeseket közülük, vagy összefüggésekre világítsunk rá, lehetôvé téve az oktulajdonítás képességét (a rövid távú memóriától eltérôen, amely csak az információk rövid ideig való megtartásáért felelôs, de azok manipulációjáért nem). A gátló múködés azt teszi lehetôvé, hogy figyelmünk és érzelmeink felett akaratlagos kontrollt gyakoroljunk. Ezáltal vagyunk képesek tudatosan átgondolt, az adott helyzetnek megfeleló viselkedést választani az automatikus, impulzív reakciók helyett. Diamond (2013) elmélete szerint a komponensek közül az elsổ kettô, azaz a munkamemória és a gátlás hamarabb fejlődik, majd ezekre épül késôbb a kognitív flexibilitás képessége, mivel az elôzô kettô megléte szükséges hozzá. A kognitív flexibilitás által képessé válunk egyes nézőpontok között váltani, más személyek helyzetébe belegondolni, viselkedésünket pedig rugalmasan változtatni a környezetben beállt változásoknak megfelelôen. Bár a végrehajtó funkciók megjelenése már néhány hónapos korban is detektálható (Nelson, Sheffield, Chevalier, Clark és Espy, 2013), folyamatosan fejlôdést mutat egészen fiatal felnôtt korig. Tipikus fejlôdés esetén ekkorra rendelkezünk a legjobb végrehajtó funkciókkal, majd idôskorban újra egy hanyatlást figyelhetünk meg (Fisk és Sharp, 2004; Juhász, 2018). Ezért különösen fontos, hogy ezen készségek felmérésekor a minta életkorának megfelelôen válasszuk meg a mérôeszközöket, hogy az megfeleló érzékenységgel bírjon az alanyok esetében, így adva megbízható eredményeket (Garon, Bryson és Smith, 2008). Jelen vizsgálatban úgy döntöttünk, hogy a munkamemóriának kifejezetten a téri-vizuális aspektusára fogunk fókuszálni, így választottuk a Corsi-kocka-tesztet. A számterjedelemteszt használatát azért vetettük el, mert a részt vevô gyermekek még csak 5 és 6 év közöttiek voltak, és óvodába jártak, így intézményes keretek között még nem tanultak számolni, és ennek torzító hatása lehet. A gátlási képesség felmérésére két eljárást is használtunk: 
a Go/no-go („Menj/Ne menj”) és a Hearts and flowers („Szívek és virágok”) nevú teszteket. A szakirodalom alapján mindkettô bevett és érzékeny mérôeszköznek bizonyul ebben a korosztályban (Davidson, Amso, Anderson és Diamond, 2006).

Ahogy már feljebb is tárgyaltuk, megalapozottan feltételezhetjük, hogy a hátrányos helyzetû gyermekek az átlagosnál nagyobb stressznek vannak kitéve, amelynek következtében emelkedett kortizolhormonszint jellemzó rájuk (Evans és Kim, 2013; Lupien és mtsai, 2001). Illetve valószínú, hogy a végrehajtó funkciók szintén kevésbé fejlettek ezeknél a gyermekeknél (Sarsour és mtsai, 2011), bár az egyes komponensek (munkamemória, gátlás, kognitív flexibilitás) és a SES közötti kapcsolatot kevesen vizsgálták külön, és ezen kevés eredmény afelé mutat, hogy azok nagyon hasonlóak az egyes komponensek esetében: kismértékú szignifikáns átlagos korrelációkkal írhatók le (Lawson és mtsai, 2018).

Blair és munkatársai (2011) korrelációs vizsgálatukban arra az eredményre jutottak, hogy a kortizolhormonszint mediálja a szülổi iskolázottság és a végrehajtó múködések közötti kapcsolatot, azonban a jövedelem esetében nem találtak ilyen hatást. Ez az eredmény azt sugallja, hogy a gyermekkori stressz lehet az egyik mechanizmus, amely hozzájárul az alacsonyabb szocioökonómiai helyzetú gyermekek rosszabb végrehajtó múködéséhez. Habár a stressznek a SES és a kognitív fejlôdés közötti kapcsolatra gyakorolt hatását empirikus módszerrel vizsgáló tanulmányok eredményei eddig kizárólag az Észak-Amerikában gyújtött adatokon alapulnak (Piccolo, Sbicigo, Grassi-Oliveira és Fumagalli de Salles, 2014), megalapozottnak túnik, hogy a stressz egy mediáló tényezô a SES és a neurokognitív végrehajtó funkció teszteken mutatott teljesítmény között (Piccolo és mtsai, 2014). Bár magyarországi mintán is születtek már vizsgálatok az egyes konstruktumokat illetôen ebben a korosztályban (Juhász, 2018; D. Molnár, 2017; Tánczos, Janacsek és Németh, 2014), de tudomásunk szerint ezen konkrét összefüggéseket egyikben sem tanulmányozták még. A jelen tanulmány célja ezeknek a tényezóknek és összefüggéseiknek a vizsgálata volt Magyarországon élô, heterogén szocioökonómiai helyzetú, óvodáskorú gyermekekbôl álló mintán.

\section{Kutatási kérdés és hipotézisek}

I. Feltételeztük, hogy Blair és munkatársai (2011) eredményei megismételhetôk egy magyar mintán. Vagyis a kortizolhormonszint mediálja a szülői iskolázottság és a végrehajtó múködések közötti kapcsolatot, azonban a jövedelem esetében nem feltételezhetô ez a hatás.

II. Feltáró módon vizsgáltuk a kortizolhormonszint szerepét a szocioökonómiai státusz (szülői iskolázottság és bevétel), illetve a végrehajtó funkciók egyes komponensei közötti kapcsolatot (munkamemória, gátlás, kognitív flexibilitás) illetôen, külön a komponensekre vonatkozóan ugyanis nincsenek korábbi mediációs hatást vizsgáló tanulmányok. Bár Lawson és munkatársainak (2018) eredményei alapján mi is hasonló erôsségú kapcsolatokat vártunk az egyes végrehajtó funkció komponensek tekintetében. 


\section{MÓDSZER}

\section{Etikai vonatkozások}

A jelen tanulmány alapjául szolgáló adatokat egy longitudinális kísérleti kutatási projekt részeként gyújtöttük, amelyben egy mindfulnessalapú intervenció óvodások szociális-érzelmi és kognitív képességeire gyakorolt hatását vizsgáltuk. A kutatást az Eötvös Loránd Tudományegyetem Pedagógiai és Pszichológiai Karának Kutatásetikai Bizottsága hagyta jóvá a 2018/238-as iktatószám alatt. Az intézmények igazgatói és a részt vevô gyermekek szülei egyaránt írásbeli, tájékozott beleegyezésüket adták a kutatásban való részvételhez. Emellett minden részt vevô gyermek szóbeli beleegyezését adta részvételéhez.

\section{Minta}

A részt vevô gyermekeket négy magyarországi óvodából, kilenc óvodai csoportból toboroztuk. Az egyik intézmény egy budapesti külvárosi kerületben helyezkedik el, ahol a gyermekek többnyire magasabb társadalmi osztályokból származnak, a második városi környezetben helyezkedik el Budapesten, ahol tipikusan középosztálybeli gyermekek vannak, a harmadik és negyedik intézmény egyike szintén Budapesten, a másik egy Pest megyei vidéki városban helyezkedik el. Az ezekbe járó gyermekekre szocioökonómiai szempontból heterogenitás jellemzô, ideértve a szélsôséges szegénységben élôket is.

Összesen 92 gyermek szülei jelentkeztek, hogy gyermekeikkel részt vegyenek kutatásunkban. A részvétel feltétele volt, hogy a gyermek nem rendelkezhetett semmilyen diagnosztizált pszichiátriai vagy neurológiai eltéréssel. (A résztvevôk színlátására és kezességére vonatkozó információkat nem gyüjtöttünk.) Két gyermeket orvosi állapot miatt ki kellett zárni, mivel a neurotipikus fejlődés feltétele nem teljesült. Ezenkívül további 10 gyermek adatait is ki kellett zárni, mivel a szülók nem töltötték ki a demográfiai adatokra vonatkozó kérdôívet. Négy gyermek esetében pedig a nyálminta szennyezett volt, tehát óket is ki kellett zárnunk. Igy a végsố mintában 76 résztvevô szerepelt. A résztvevôk 59\%-a volt fiú. A részt vevô családok 50\%-a él a fốvárosban, 3\%-a városban, $11 \%$-a községben, $12 \%$-a pedig faluban. A résztvevôkre vonatkozó további leíró demográfiai információkat az 1. táblázat tartalmazza.

\section{Méröeszközök}

\section{Szocioökonómiai státusz (SES)}

A demográfiai adatokra vonatkozó információkat a szülôktôl gyújtöttük, papíralapú, önbevallásos, kérdốives módszerrel. A szocioökonómiai státuszt két komponens alapján határoztuk meg: szülooi iskolázottság és a család bevétele. A szülői iskolázottságot a két elsôdleges gondozó legmagasabb iskolai végzettségének átlagolásával határoztuk meg. A család bevételére pedig a havi nettó jövedelmükból következtettünk. (A kérdôív vonatkozó tételeit lásd a mellékletben.) A mintában a szülook végzettségének és a családok havi bevételének megoszlása az 1-2. ábrán látható. 
1. táblázat. A résztvevốk demográfiai adatai

\begin{tabular}{lcccc}
\hline & Átlag & Szórás & Minimum & Maximum \\
\hline Gyermek életkora (hónap) & 70,85 & 0,69 & 52 & 83 \\
\hline $\begin{array}{l}\text { Elsốdleges gondozó életkora } \\
\text { (év) }\end{array}$ & 36,22 & 7,18 & 23 & 60 \\
\hline $\begin{array}{l}\text { Másodlagos gondozó életkora } \\
\text { (év) }\end{array}$ & 39,76 & 5,31 & 25 & 50 \\
\hline $\begin{array}{l}\text { A háztartásban élốk száma } \\
\text { (fó) }\end{array}$ & 4,62 & 1,95 & 2 & 16 \\
\hline $\begin{array}{l}\text { A gyermekkel egy szobában } \\
\text { alvók száma (fó) }\end{array}$ & 1,52 & 1,25 & 0 & 4 \\
\hline
\end{tabular}

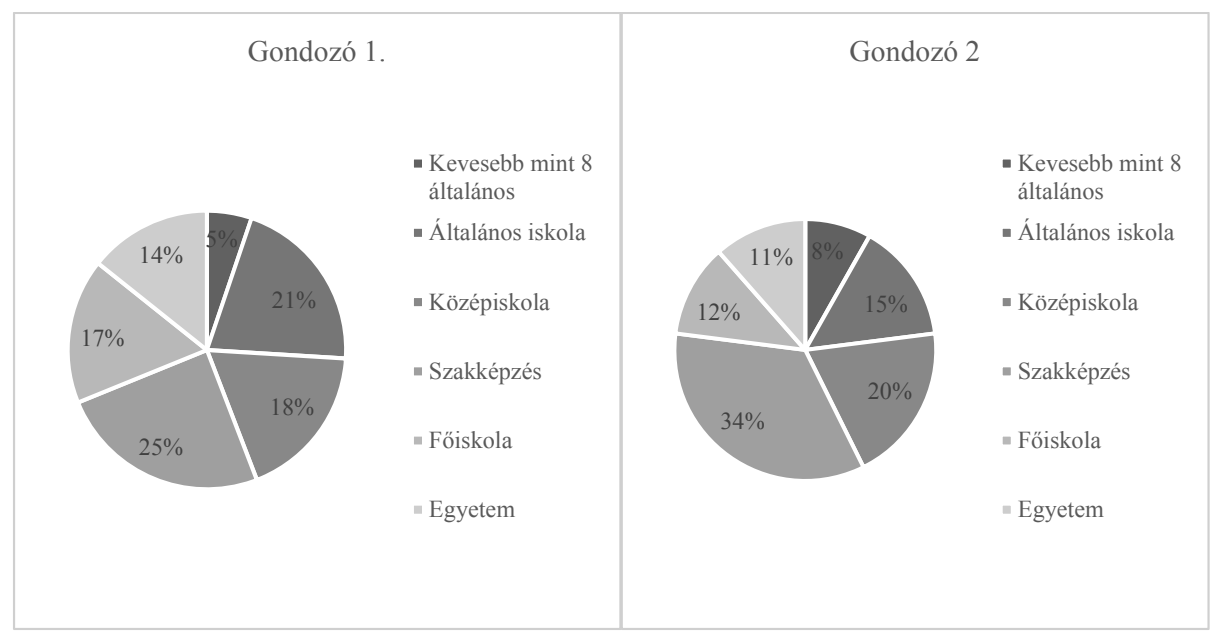

1. ábra. Az elsôdleges és másodlagos gondozók legmagasabb iskolai végzettségének megoszlása

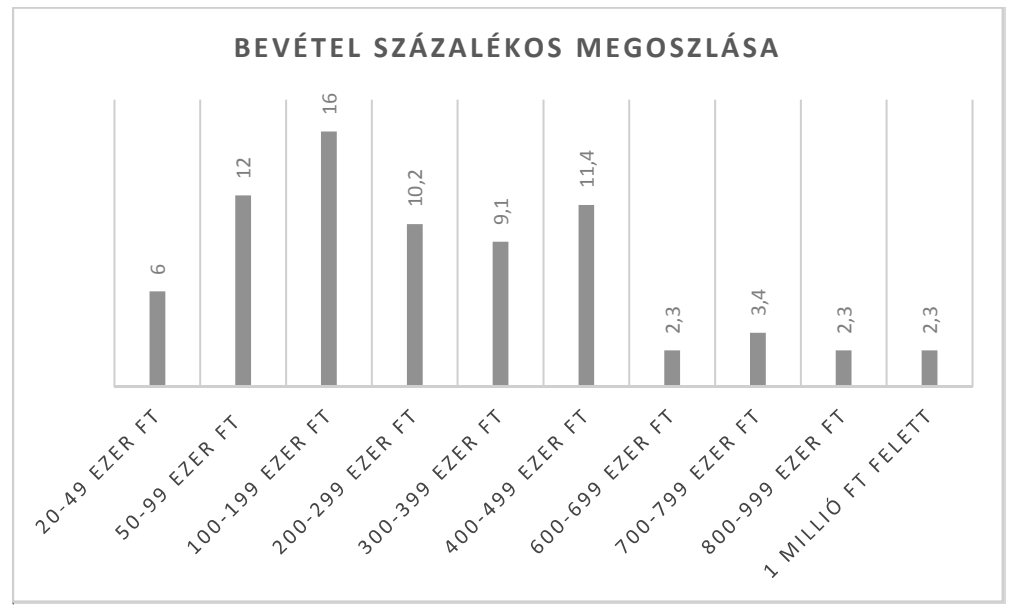

2. ábra. A családok havi nettó jövedelmének százalékos megoszlása 
Stressz

A kortizolhormonszintet nyálmintából határoztuk meg. Jelen tanulmány során a reggeli kortizolalapszintjébôl következtettünk a résztvevôk stresszszintjére, amelyet az intézménybe érkezéskor mért háromnapi érték (C1, C2, C3) átlagolásával számítottunk ki. A gyermekektôl reggel, az óvodai csoportszobában vették le a mintát felkészült kutatóasszisztensek. A gyermekeknek annyi volt a feladatuk, hogy egy szívószál segítségével egy Eppendorf csóbe csorgassanak minimum 0,5 ml nyálat. Az eljárás teljes mértékben noninvazív és fájdalommentes volt, semmiféle kellemetlenséggel nem járt a gyermekek számára. A mintavételt követôen a mintagyújtô Eppendorf csöveket rögtön hútôtáskába helyeztünk, majd -20 fokon tároltuk. A minták mérését az MTA Molekuláris Kísérleti Orvostudományi Kutatóintézetében múködô Neuroendokrinológiai Kutatócsoport munkatársai végezték, ELIZA-módszer alkalmazásával.

\section{Végrehajtó funkciók}

A gyermekek végrehajtó funkcióit három különbözô, életkoruknak megfelelô neuropszichológiai teszt alkalmazásával mértük fel.

1. A Corsi-kocka-teszt számítógépes változatát (Peres, 2013) használtunk a rövid távú memória (elôre verzió), illetve a munkamemória (fordított verzió) felmérésére. Ebben a feladatban a gyermekeknek kilenc darab, egymáshoz képest random módon elhelyezkedó sötétkék négyzetet mutattunk a képernyoon. Az egyre növekvô számú négyzetek színe sárgára változott sorban egymás után egy-egy másodpercre. A kezdetben kéttagú sorozat tagjainak száma akkor emelkedik meg eggyel, ha a résztvevó helyesen elismétli a sorrendet. A gyermek feladata, hogy a felvillanás sorrendjében a négyzetekre mutatva jelezze az általa megjegyzett szekvenciát. A legnagyobb számú, helyes sorrendben elismételt sorozatban a felvillanó négyzetek száma a gyermek rövid távú memória és munkamemória pontszáma. A mért változónk a maximális terjedelem volt. (A jelen tanulmányban csak a fordított verzión elért pontszámot használtuk fel, amely a munkamemória készségre vonatkozik.)

2. A Go/No-Go teszt (Wiebe, Sheffield és Espy, 2012) paradigma a gátló múködések felmérésére szolgál. A gyermekek halakat („go” inger) és cápákat („no-go” inger) látnak megjelenni a számítógép kijelzőjén. Az ingerek 2/3 go és 1/3 no-go arányban oszlottak meg. A gyerekek feladata az volt, hogy megnyomják a „Szünet” gombot akkor, ha halat látnak, de ne nyomjanak gombot, ha cápa jelenik meg. A cápák, azaz a „no go” ingerek esetén mutatott pontosság átlaga a gyermek gátlási képessége. A mért változónk a hibázások száma volt.

3. A Hearts and Flowers teszt (Diamond és Wright, 2014) során a képernyôn szív és virág formák jelentek meg vagy a jobb, vagy a bal oldalon. Amikor egy szív jelent meg, a gyermek feladata az volt, hogy a megjelenés helyével azonos oldalon nyomjon gombot (kongruens próbák), de amikor virág forma jelent meg, akkor a megjelenéssel ellentétes oldalon kellett gombot nyomnia (inkongruens próbák). A teszt három részre tagolódik, a fix kongruens részben kizárólag szív alakok jelennek meg. A fix inkongruens részen kizárólag virágok jelennek 
meg. A mix részben pedig szívek és virágok is, azaz kongruens és inkongruens próbák véletlenszerúen jelennek meg. A fix kongruens részen mutatott pontosság a gyermek gátlási képességeinek mutatója, a mix rész során mért pontosság pedig a kognitív flexibilitás jelzője. A mért változónk a hibázások száma volt.

A mért változók közül a gátló múködésekre két teszt eredményeiból is következtethetünk (Go/No-go, Hearts és Flowers), ezen pontszámok standardizálásával és átlagolásával számítottuk ki a gátlás kimeneti mutatót. A különbözô kimeneti mutatókon kívül, amelyek az egyes komponensekre vonatkoznak, egy aggregát pontszámot is számítottunk az összes végrehajtó funkcióra vonatkozóan (VF), amely az egyes komponensek standardizált átlaga.

\section{Eljárás}

Az adatokat az óvodákban kutatóasszisztensek gyújtötték. A nyálmintákat három egymást követố napon vettük (kedden - C1, szerdán - C2, csütörtökön - C3), közvetlenül a gyermekek óvodába érkezése után (7 és 9 óra között). Késôbb, egy csendes külön szobában vettünk egy következô nyálmintát (C4), majd felkészült kutatóasszisztens vezetésével a gyermekek kitöltöttek egy digitális kognitív tesztcsomagot (itt kerültek felvételre a végrehajtó funkció tesztek) egy laptopon, és elvégeztük a Trier Szociális Teszt gyermekekre adaptált verzióját (Trier Social Stress Test for Children). Ez a feladat körülbelül 30 percet vett igénybe. Az ülés második felében átmentek a gyermekek egy másik helyiségbe, ahol szintén egy kutatóasszisztens 10 percenként további 4 nyálmintát (C5, C6, C7, C8) gyújtött tôlük (kb. 30 perc). Ez idó alatt a gyermekek kis csoportokban (2-3 fö) ültek egy asztal körül, színeztek, rajzoltak. (Ezen minták elemzése a TSST-C teszt kiértékeléséhez szükséges. Mivel jelen vizsgálatban errôl a tesztrôl nem számolunk be, így ezek jelen tanulmányban nem kerülnek bemutatásra.) Az ülés végén minden gyermek oklevelet kapott, amelyre választhatott egy felragasztható matricát, majd visszakísérték óket az asszisztensek a csoportszobába.

Ezenkívül a szülooktôl származó demográfiai információk begyújtése kérdôíves módszerrel történt. A kérdôíveket az óvodapedagógus osztotta ki névre szóló borítékban. A szülốk az intézményben vagy otthon töltötték ki a kérdôívet, majd - az anonimitás érdekében - egy jelöletlen, lezárt borítékban adták vissza az óvónôknek. (A kérdôíven sem szerepelt már a gyermek neve, kizárólag az azonosító száma.)

\section{Statisztikai elemzési terv}

A statisztikai elemzéseket az SPSS Statistics 21.0 programmal végeztük. Az egyes változók közötti együtt járást Pearson-féle korrelációval ellenôriztük. A hipotézisek teszteléséhez mediációs modellt alkalmaztunk, amelyhez a PROCESS makrót használtuk (Hayes, 2017). A mediációs modellekben 5000 bootstrappeléssel számítottunk 95\%-os konfidenciaintervallumot. Amennyiben ez az intervallum nem tartalmazza a nullát, a hatás szignifikáns. 


\section{EREDMÉNYEK}

A változókra vonatkozó leíró adatokat és nyers korrelációkat a 2. táblázat tartalmazza.

2. táblázat. A vizsgált változókra vonatkozó leíró adatok és nyers korrelációk

\begin{tabular}{|c|c|c|c|c|c|c|c|c|c|}
\hline Változó & $\begin{array}{l}\text { Átlag } \\
\text { (SD) }\end{array}$ & Min & Max & 1 & 2 & 3 & 4 & 5 & 6 \\
\hline 1 kortizol & $\begin{array}{c}4,71 \\
(2,58)\end{array}$ & 1,31 & 18,35 & & & & & & \\
\hline 2 végzettség & $\begin{array}{c}3,64 \\
(1,36)\end{array}$ & 1 & 6,33 & $-0,27 * *$ & & & & & \\
\hline 3 bevétel & $\begin{array}{c}5,3 \\
(2,6)\end{array}$ & 2 & 13 & $-0,04$ & $0,49 * *$ & & & & \\
\hline $\begin{array}{ll}\text { munka- } \\
\text { memória }\end{array}$ & $\begin{array}{c}2,35 \\
(1,18) \\
\end{array}$ & 0 & 6 & $-0,16$ & $0,34 * *$ & $0,24 *$ & & & \\
\hline 5 gátlás & $\begin{array}{l}0,004 \\
(0,86)\end{array}$ & $-3,01$ & 1,08 & 0,07 & $0,51 * *$ & $0,26^{* *}$ & $0,35^{* *}$ & & \\
\hline 6 flexibilitás & $\begin{array}{l}12,71 \\
(7,19)\end{array}$ & 0 & 25 & 0,12 & $0,29 * *$ & 0,05 & $0,33 * *$ & $0,36^{* * *}$ & \\
\hline $7 \quad \mathrm{VF}$ & $\begin{array}{c}-0,008 \\
(0,71)\end{array}$ & $-2,23$ & 1,37 & 0,03 & $0,52 * *$ & $0,27 * *$ & $0,69 * *$ & $0,85^{* *}$ & $0,68^{* *}$ \\
\hline
\end{tabular}

$V F$ : végrehajtó funkciók

**: $\mathrm{p}<.05, *: \mathrm{p}<.10$

\section{Hipotézistesztelés}

Az elsố hipotézis teszteléséhez két mediációs modell ellenôrzésével vizsgáltuk meg a végzettség (3. ábra) és a bevétel (4. ábra) végrehajtó funkciókkal való direkt kapcsolatát, illetve a kortizolszint ezen kapcsolatokra gyakorolt hatását. Az iskolázottság és a kortizolszint között közepes mértékú, szignifikáns negatív kapcsolat volt, míg a kortizolszint és a végrehajtó funkciók között gyenge, tendenciaszintú kapcsolat mutatkozott. Az ábrán továbbá látható, hogy az iskolázottság és a végrehajtó funkciók közötti köz-

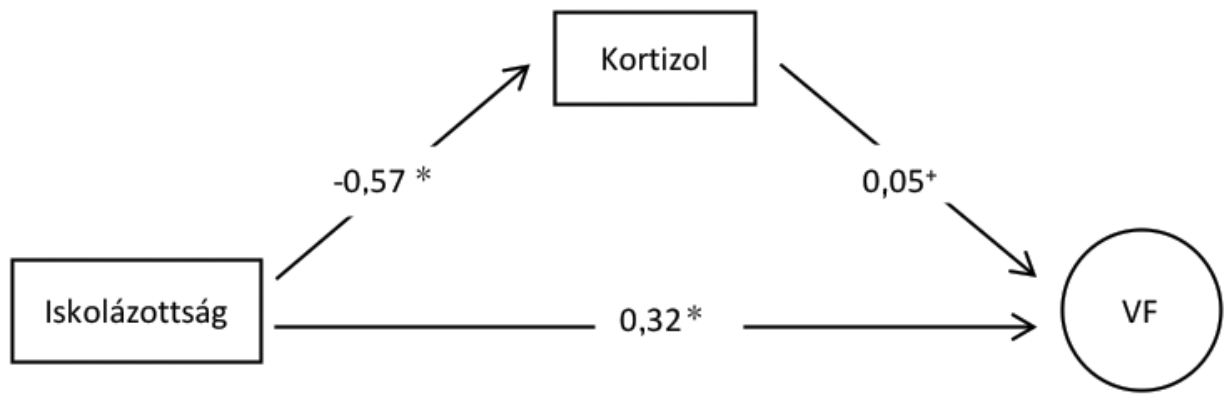

3. ábra. A kortizol mediáló hatása a végzettség és végrehajtó funkciók közötti kapcsolat esetében (A szignifikáns utakat „*”, a tendenciaszintû́ kapcsolatokat „,” jelekkel jelöltük.) 


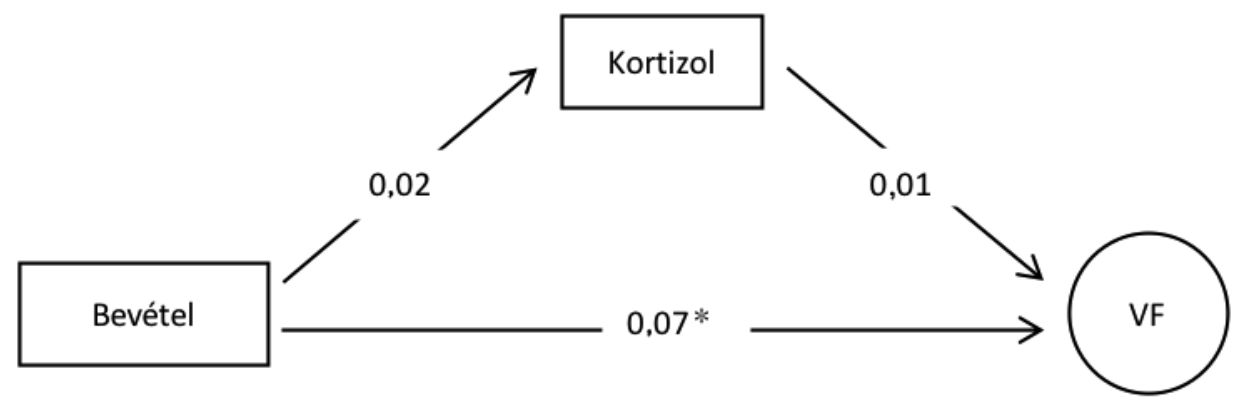

4. ábra. A kortizol mediáló hatása a végzettség és végrehajtó funkciók közötti kapcsolat esetében. (A szignifikáns utakat „," jellel jelöltük.)

vetlen út is szignifikáns, alacsony mértékú kapcsolatot jelzett. Ezzel szemben a bevétel esetében nem találtunk szignifikáns kapcsolatot a kortizolon keresztül, illetve a direkt kapcsolat a végrehajtó funkciókkal is, bár szignifikáns, de nagyon alacsony mértékú.

A változók közötti direkt és indirekt kapcsolat paramétereit a 3. táblázat tartalmazza. Mint az látható, mind a családi bevételnek, mind pedig a szülôi végzettségnek szignifikáns direkt hatása volt a gyermekek végrehajtó múködésére, azonban a gyermekek kortizolszintjének csak a végzettség és végrehajtó múködések kapcsolatára volt szignifikáns mediáló hatása.

3. táblázat. A szülói végzettség, illetve a család bevétele és a végrehajtó funkciók közötti direkt hatás, valamint a kortizol mint mediátor változó esetében mutatott indirekt hatás

\begin{tabular}{lcccc}
\hline & \multicolumn{2}{c}{ Direkt hatás } & \multicolumn{2}{c}{ Indirekt hatás } \\
\cline { 2 - 5 } & $\beta$ & $95 \% \mathrm{Cl}$ & $\beta$ & $95 \% \mathrm{Cl}$ \\
\hline Végzettség - Kortizol - VF & 0,36 & $0,20-0,43$ & $-0,03$ & $\begin{array}{c}(-0,07)- \\
(-0,003)\end{array}$ \\
\hline Bevétel - Kortizol - VF & 0,07 & $0,004-0,14$ & 0,0001 & $\begin{array}{c}(-0,005)- \\
0,10\end{array}$ \\
\hline
\end{tabular}

A második kutatási kérdéshez, hogy a SES és a végrehajtó funkciók egyes komponensei közötti kapcsolatok esetében a kortizolszint milyen szerepet játszik, szintén mediációs modelleket alkalmaztunk. Az eredmények a 4. és 5. táblázatban láthatók. Ami a végzettséget illeti, a különbözô komponensek esetében hasonló eredményre jutottunk, mint a közös végrehajtó funkció pontszámok esetében, azaz hogy a direkt kapcsolatok erôsebbek, mint az indirekt összefüggések, bár a munkamemória kivételével az indirekt utak is szignifikáns negatív összefüggést mutattak. A bevételt illetôen csak a gátló múködések esetében találtunk szignifikáns, kismértékú direkt utat. Ezenkívül egyik komponensnél sem találunk szignifikáns kapcsolatokat sem a direkt, sem az indirekt út esetében. 
4. táblázat. A szülői végzettség és az egyes végrehajtó funkció komponensek (munkamemória, gátlás, flexibilitás) közötti direkt hatás, valamint a kortizol mint mediátor változó esetében mutatott indirekt hatás

\begin{tabular}{lcccc}
\hline & \multicolumn{2}{c}{ Direkt hatás } & \multicolumn{2}{c}{ Indirekt hatás } \\
\cline { 2 - 5 } & $\beta$ & $95 \% \mathrm{Cl}$ & $\beta$ & $95 \% \mathrm{Cl}$ \\
\hline $\begin{array}{l}\text { Végzettség - Kortizol - Munka- } \\
\text { mémória }\end{array}$ & 0,28 & $0,07-0,49$ & 0,03 & $\begin{array}{c}(-0,02)- \\
0,10\end{array}$ \\
\hline Végzettség - Kortizol - Gátlás & 0,39 & $0,25-0,53$ & $-0,04$ & $\begin{array}{c}(-0,10)- \\
(-0,01)\end{array}$ \\
\hline Végzettség - Kortizol - Flexibilitás & 1,93 & $0,58-3,29$ & $-0,42$ & $\begin{array}{c}(-0,98)- \\
(-0,06)\end{array}$ \\
\hline
\end{tabular}

5. táblázat. A bevétel és az egyes végrehajtó funkció komponensek (munkamemória, gátlás, flexibilitás) közötti direkt hatás, valamint a kortizol mint mediátor változó esetében mutatott indirekt hatás

\begin{tabular}{lcccc}
\hline & \multicolumn{2}{c}{ Direkt hatás } & \multicolumn{2}{c}{ Indirekt hatás } \\
\cline { 2 - 5 } & $\beta$ & $95 \% \mathrm{Cl}$ & $\beta$ & $95 \% \mathrm{Cl}$ \\
\hline & $-0,10$ & $(-0,01)-$ & $-0,002$ & $(-0,04)-$ \\
Bevétel - Kortizol - Munkamemória & & 0,22 & & 0,02 \\
\hline \multirow{3}{*}{ Bevétel - Kortizol - Gátlás } & 0,10 & $0,02-$ & 0,0004 & $(-0,01)-$ \\
\hline \multirow{2}{*}{ Bevétel - Kortizol - Flexibilitás } & $-0,11$ & 0,19 & & 0,02 \\
\hline
\end{tabular}

\section{DISZKUSSZIÓ}

A tanulmány célja az volt, hogy magyarországi mintán megvizsgáljuk a szocioökonómiai helyzet és az olyan alapvetô kognitív funkciók, mint az egyes végrehajtó múködések közötti kapcsolatot óvodáskorú gyermekeknél. Továbbá, hogy tanulmányozzuk a stressz mint potenciális háttérmechanizmus szerepét a két változó kapcsolatát illetốen.

Az elsô hipotézisünk, amely szerint a kortizolhormonszint csak a szülôi iskolázottság és a gyermek végrehajtó funkciói közötti kapcsolatot mediálja, részben helytálló volt. Sikerült megerôsíteni azokat a korábbi eredményeket, miszerint a szülői iskolázottsággal való összefüggésben van szerepe a stressz szintjének, míg az anyagi helyzettel való kapcsolatban nincs (Blair és mtsai, 2011). Sót az anyagi helyzet és a végrehajtó funkciók között direkt szignifikáns kapcsolatot sem találtunk, míg a szülői iskolai végzettség és a végrehajtó funkciók között igen.

A második kutatási kérdésben a szüloói végzettség, illetve bevétel kapcsolatát vizsgáltuk külön-külön a végrehajtó funkciók egyes komponenseivel, azaz a munkamemóriával, a gátló múködéssel, illetve a kognitív flexibilitással. Az analízisek eredményei nagyon hasonló mintázatokat mutattak, mint az aggregát végrehajtó funkciók pont- 
számának esetében. Ez alapján arra következtethetünk, hogy a végrehajtó funkciók egyes komponensei nem viselkednek eltérôen, hasonlóan azokhoz az eredményekhez, amelyeket Lawson és munkatársai (2018) a végrehajtó funkció komponensei és a SES kapcsolatára vonatkozóan találnak.

Legfőbb eredményünk tehát, hogy a kortizolszintnek részleges mediáló szerepe van a szülői iskolázottság és a gyermeki végrehajtó funkciók kapcsolatában. Fontos megjegyezni, hogy nem teljes mediációt találtunk, tehát a két változó közötti kapcsolatot nem magyarázza teljes mértékig a stressz. Ez alapján feltételezhetjük, hogy bár részben az emelkedett stresszszint lehet a felelôs a gyengébb végrehajtó múködésekért a hátrányosabb társadalmi helyzetben nevelkedó gyermekek esetében, egyéb tényezôk szintén szerepet játszanak benne. A szakirodalomból tudjuk például, hogy az alacsonyabb szocioökonómiai státuszú gyermekek kevesebb tápanyagban gazdag élelmiszert fogyasztanak (World Health Organization, 2020), mint például zöldségek, gyümölcsök, húsfélék, tejtermékek, szemben a jellemzôen szénhidrátalapú, energiában gazdag ételekkel. Ez a típusú étrend pedig például vas- (Venegas-Aviles Rodríguez-Ramírez, Monterrubio-Flores és García-Guerra, 2020), vitamin- (Ngoma és Mayimbo, 2017; Zang és mtsai, 2017) és magnéziumhiányhoz (Marshall, Teo, Shanahan, Legette és Mitmesser, 2020), illetve egyéb ásványi anyagok csökkent beviteléhez (Tomkins, 2001) vezethet, ami többek között a kognitív, illetve a szocioemocionális fejlődésben lemaradást eredményez (Brown és Pollitt, 1996; Kvestad és mtsai, 2017; Lozoff, 2007). Emellett a kognitív fejlôdésben igen jelentôs szerepe van a közvetlen környezet feltételeinek is. Jellemzô, hogy a hátrányos helyzetben élố gyermekek zsúfoltabb háztartásokban élnek, magasabb ezekben a családokban a háztartás rendezetlensége, zajszintje (Evans, Gonnella, Marcynyszyn, Gentile és Salpekar, 2005). A háztartás rendezetlensége pedig szignifikáns moderátorának bizonyul a SES és a gyermek végrehajtó funkciói közötti kapcsolatnak (St. John és Tarullo, 2020). A háztartás rendezettségének alacsony szintje kedvezôtlen hatással lehet a gyermek pihenésére, alvására is (Berger és mtsai, 2019). Továbbá a család napi rutinja is jellemzôen kevésbé kiszámítható a hátrányos körülmények között élook esetében (Britto, Fuligni és Brooks-Gunn, 2002). Feltételezhetô, hogy a délutáni alvás, esti lefekvés, reggeli ébredés ideje is kevésbé rendszeres. Mind a rendszertelen, rövid, mind pedig a gyenge alvásminôség negatívan befolyásolja a kognitív készségeket (Buckhalt, 2011; Buckhalt, El-Sheikh és Keller, 2007). Szintén széles körben kutatott terület a hátrányos helyzetben nevelkedô gyermekek esetében a szülô nevelôii kompetenciáinak minôsége. Az eredmények azt mutatják, hogy ezekben a családokban rendszerint alacsonyabb szintûek a felnôttek ezen készségei, ami szintén hátrányosan befolyásolhatja a gyermek fejlôdését (Deater-Deckar, Chen, Wang és Bell, 2012). Valamint szerepet játszhat az is, hogy az alacsony szocioökonómiai helyzetú gyermekek kevésbé jutnak hozzá olyan fejlesztésekhez, korai intervenciókhoz, amelyek az esetleges atipikus kognitív fejlôdés negatív hatásait csökkenthetnék (Morgan, Farkas, Hillemeier és Maczuga, 2012). A fenti vizsgálatok az esetleges befolyásoló tényezók hatását gyakran csak a szocioökonómiai státusz egy-egy komponensével, jellemzôen inkább az anyagi helyzettel vetették össze, vagy egy, a szocioökonómiai státuszra vonatkozó, aggregát pontszámmal. A vizsgálatunkban rámutattunk, hogy érdemes az egyes SES-komponenseket egymástól függetlenül is vizsgálni, illetve összevetni az eredményeket, hiszen elképzelhetô, hogy az anyagi helyzettel, a végzettséggel vagy akár a 
foglalkoztatottsággal eltérô mértékben függnek össze a mért konstruktumok. Ezáltal azonosíthatóvá válhat többek között az is, hogy az adott intervenció a célját pontosan mely faktorokra gyakorolt hatásával érheti el.

Természetesen ezen eredmények keresztmetszeti képet mutatnak, és együtt járásokon alapulnak. Ahhoz, hogy a változók kauzális kapcsolatairól következtetéseket vonhassunk le, kísérleti elrendezésben, például kontrollált hatásvizsgálatok segítségével szükséges vizsgálnunk az adott kérdést. A jelen eredmények egy ilyen kísérlet kidolgozásához hasznos támpontot nyújthatnak. Az egyik, hogy ha hatékony intervenciót szeretnénk kidolgozni hátrányos helyzetben élő gyermekek kognitív készségfejlesztésére, azt valószínúleg komplex módon kell összeállítanunk, akár több potenciális háttérmechanizmus változtatását is célozva. Egyrészt azt látjuk, hogy a szülôi aluliskolázottság szerepe hangsúlyosabb a gyermek gyengébb végrehajtó múködéseinek szempontjából, mint az anyagi jóllété. Egy esetleges intervenciós program kidolgozásánál ennek megfelelốen a szülôi készségfejlesztést vagy akár az oktatáshoz, továbbtanuláshoz való hozzáférést is érdemes támogatni. Továbbá azt találjuk, hogy indirekt módon a fokozott stressz is hozzájárulhat az alacsonyabb szintú végrehajtó múködésekhez. Ennek megfelelốen megalapozottan feltételezhetjük, hogy maga a stressz csökkentése is hatékony lehet. Egyfajta preventív szemléletben tehát logikus cél lehet, ha a gyermeket érô stresszhatásokat próbáljuk csökkenteni, de közvetlenül a gyermeket célzó stresszkezelési technika elsajátítását támogató program is hatékony intervenció lehet. Számos módszer bizonyult hatásosnak ilyen szempontból a gyermekek számára, mint például a mindfulness (Zenner, Herrnleben-Kurz és Walach, 2014), a relaxáció és egyéb kognitív megküzdést, mentalizációt segítô módszerek (Kraag, Zeegers, Kok, Hosman és Abu-Saad, 2006), vagy akár a jóga (White, 2012). A megfeleló intervenció megválasztásához természetesen szükséges a stresszt kiváltó tényezôk pontos feltárása.

\section{Limitációk}

A kutatás limitációinak egy része a használt méróeszközök és eljárások esetleges torzító hatásából fakad. A vizsgálat során a résztvevốk stresszszintjére a nyálban mért kortizolhormonszintből következtettünk. Ezen eljárás alkalmazása felnôtteknél közvetlenül az ébredést követô egy órában gyújtött minták mérésével bevett. Azonban mivel itt óvodáskorú gyermekekrôl volt szó, akik önálló mintavételre még nem képesek, valamint olyan gyermekek is részt vettek a kutatásban, akiknek a családi körülményeik nem voltak megfelelôk ahhoz, hogy a szüleik segítségével történjen meg a mintavétel, így arra a döntésre jutottunk, hogy napi egy mintát veszünk (három egymást követô napon) reggel, lehetôleg hasonló időpontban, amikor az intézménybe megérkeznek. Ez azonban az ébredéstôl eltelt idô szempontjából gyermekenként eltérô lehet, így a kortizol napi ingadozása befolyásolhatja a mért eredményeket. A továbbiakban, ha ezt a módszert választjuk, akkor érdemes a szülootôl megkérdezni a gyermek ébredésének idôpontját, és korrigálni ennek hatását a mért adatokra.

A kutatás során kizárólag a hideg végrehajtó funkciókat („cool executive functions”) mértük fel, amelyek a szülôi iskolázottsággal mutattak összefüggéseket. Nem vizsgáltuk viszont az úgynevezett meleg végrehajtó múködéseket, mint például az impulzi- 
vitás vagy a jutalomkésleltetés képessége, amely viszont összefügg a hátrányos anyagi helyzettel (Burdick, Roy és Raver, 2013; Evans és English, 2002; Lynam és mtsai, 2000). További vizsgálatokba érdemes lenne ilyen típusú végrehajtó funkciókat is bevonni.

További limitációk származtathatók a minta jellegzetességeiból is. Egyrészt a bevont gyermekek egy szúk életkori csoporthoz tartoztak, így a kor hatását a feltárt összefüggésre ellenôrizni nem tudjuk. Mindazonáltal további vizsgálatokban érdemes lenne feltárni ezen idôi tényezố szerepét is. Jelen vizsgálatba közvetlenül az iskolakezdés elôtt álló gyermekeket vontunk be. Kifejezetten érdekes lenne az iskolakezdést követô években is vizsgálni ezt a kérdést, mivel korábbi kutatási eredmények arra engednek következtetni, hogy a közoktatásba való bekapcsolódásnak egyfajta protektív, hátránykompenzáló szerepe is lehet. Lupien és munkatársai (2001) például arra a következtetésre jutottak, hogy a SES befolyásoló hatása a stresszreaktivitásra középiskoláskorra megszúnik.

A résztvevôinkkel kapcsolatban azonban meg kell jegyeznünk azt is, hogy vizsgálatba bevont minta nem tekinthetô a SES szempontjából reprezentatívnak a hazai népességre vonatkoztatva, így nem feltétlenül általánosíthatók a levont következtetések a teljes populációra. Továbbá a kutatásunk az elrendezésébôl kifolyólag ok-okozati következtetések levonására nem alkalmas. A jövôben érdemes lenne a vizsgált változókat manipulálva kísérleti elrendezésben is vizsgálni az adott kérdést.

\section{KÖVETKEZTETÉSEK}

A vizsgálatunk célja az volt, hogy óvodás gyermekek alapvető kognitív készségeit, azon belül is a végrehajtó funkcióik fejlettségi szintjét vizsgáljuk a szocioökonómiai státusz két komponensének, a szülôi iskolázottságnak és az anyagi helyzetnek a függvényében, illetve tanulmányozzuk, hogy a kapcsolatra milyen hatást gyakorol a kortizolhormon alapszintje mint a stressz egy objektív indikátora. Az eredményeink azt mutatják, hogy míg az anyagi helyzet nem meghatározó sem a stresszszinten keresztül, sem direkt módon a végrehajtó funkciók fejlettségének szempontjából, addig a szülői iskolázottságnak fontos szerepe van. A szülő iskolai végzettsége közvetlen módon szignifikáns kapcsolatban áll a gyermek végrehajtó múködésének fejlettségével, valamint a stressz részlegesen mediálja ezt a kapcsolatot. Ez azt jelenti, hogy ugyan a stressz szerepét mint egyik lehetséges háttérmechanizmust megerôsítettük, azonban ezenkívül egyéb tényezôk is állhatnak a háttérben. Feltételezhetô, hogy a hátrányos szocioökonómiai helyzet igen komplex folyamatok mentén fejti ki hatását. Ezen komplex mechanizmusok elaboráltabb vizsgálatok általi megértése pedig elengedhetetlenül szükséges a minél célzottabb, hatékonyabb intervenciós programok fejlesztéséhez.

\section{KÖSZÖNETNYILVÁNÍTÁS}

A tanulmány alapját képzô kutatási projekt az Új Nemzeti Kiválóság Program 2019/20 és az Eötvös Loránd Kutatási Hálózat LP-2018-21/2018 számú Lendület II. Támogatás keretei között valósult meg. A kutatást az Eötvös Loránd Tudományegyetem 
Pedagógiai és Pszichológiai Karának Kutatásetikai Bizottsága hagyta jóvá a 2018/238-as iktatószám alatt.

A szerzôk az alábbi hozzájárulást nyújtották a tanulmány elkészítéséhez. Ötlet és elrendezés: K.R., F.J., T.Zs.K., adatgyújtés: K.R., statisztikai elemzés: K.R., T.Zs.K., interpretáció: K.R., F.J., T.Zs.K., kézirat elkészítése: K.R., F.J., T.Zs.K.

\section{IRODALOM}

Berger, R. H., Diaz, A., Valiente, C., Eisenberg, N., Spinrad, T. L., Doane, L. D., \& Southworth, J. (2019). The association between home chaos and academic achievement: The moderating role of sleep. Journal of Family Psychology, 33(8), 975-981.

Blair, C., \& Diamond, A. (2008). Biological processes in prevention and intervention: The promotion of self-regulation as a means of preventing school failure. Development and Psychopathology, 20(3), 899.

Blair, C., \& Razza, R. P. (2007). Relating effortful control, executive function, and false belief understanding to emerging math and literacy ability in kindergarten. Child Development, 78(2), 647-663.

Blair, C., Granger, D. A., Willoughby, M., Mills-Koonce, R., Cox, M., Greenberg, M. T., \& FLP Investigators. (2011). Salivary cortisol mediates effects of poverty and parenting on executive functions in early childhood. Child Development, 82(6), 1970-1984.

Britto, P. R., Fuligni, A. S., \& Brooks-Gunn, J. (2002). Reading, rhymes, and routines: American parents and their young children. In Halfon, N., McLearn, K. T., \& Schuster, M. A. (Eds), Child Rearing in America: Challenges Facing Parents with Young Children (pp. 117-145). Cambridge University Press.

Brown, J. L., \& Pollitt, E. (1996). Malnutrition, poverty and intellectual development. Scientific American, 274(2), 38-43.

Buckhalt, J. A. (2011). Insufficient sleep and the socioeconomic status achievement gap. Child Development Perspectives, 5(1), 59-65.

Buckhalt, J. A., El-Sheikh, M., \& Keller, P. (2007). Children's sleep and cognitive functioning: race and socioeconomic status as moderators of effects. Child Development, 78(1), 213-231.

Burdick, J. D., Roy, A. L., \& Raver, C. C. (2013). Evaluating the Iowa Gambling Task as a direct assessment of impulsivity with low-income children. Personality and Individual Differences, 55(7), 771-776.

Casady, A., Diener, M., Russell, I., \& Wright, C. (2001). Attachment Security among Families in Poverty: Maternal, Child, and Contextual Characteristics. Biennial Meeting of the Society for Research in Child Development. Minneapolis, MN, April 19-22, 2001.

Casey, J. A., Morello-Frosch, R., Mennitt, D. J., Fristrup, K., Ogburn, E. L., \& James, P. (2017). Race/ethnicity, socioeconomic status, residential segregation, and spatial variation in noise exposure in the contiguous United States. Environmental Health Perspectives, 125(7), 077017.

Crnic, K. A., Gaze, C., \& Hoffman, C. (2005). Cumulative parenting stress across the preschool period: Relations to maternal parenting and child behaviour at age 5. Infant and Child Development: An International Journal of Research and Practice, 14(2), 117-132.

Davidson, M. C., Amso, D., Anderson, L. C., \& Diamond, A. (2006). Development of cognitive control and executive functions from 4 to 13 years: Evidence from manipulations of memory, inhibition, and task switching. Neuropsychologia, 44(11), 2037-2078.

Deater-Deckard, K., Chen, N., Wang, Z., \& Bell, M. A. (2012). Socioeconomic risk moderates the link between household chaos and maternal executive function, Journal of Family Psychology, 26(3), 391-399. 
Diamond, A. (2013). Executive functions. Annual Review of Psychology, 64, 135-168.

Diamond, A., \& Wright, A. (2014). An effect of inhibitory load in children while keeping working memory load constant. Frontiers in Psychology, 5, 213.

Duncan, G. J., Magnuson, K., \& Votruba-Drzal, E. (2017). Moving beyond correlations in assessing the consequences of poverty. Annual Review of Psychology, 68, 413-434.

Ercse, K. (2019). Az egyházi fenntartású iskolák és a szelekció, szegregáció kapcsolata. Iskolakultúra, 29(7), 50-72.

Evans, G. W. (2004). The environment of childhood poverty. American Psychologist, 59(2), 77.

Evans, G. W., \& English, K. (2002). The environment of poverty: Multiple stressor exposure, psychophysiological stress, and socioemotional adjustment. Child Development, 73(4), $1238-1248$.

Evans, G. W., \& Kim, P. (2013). Childhood poverty, chronic stress, self-regulation, and coping. Child Development Perspectives, 7(1), 43-48.

Evans, G. W., Gonnella, C., Marcynyszyn, L. A., Gentile, L., \& Salpekar, N. (2005). The role of chaos in poverty and children's socioemotional adjustment. Psychological Science, 16(7), $560-565$.

Fisk, J. E., \& Sharp, C. A. (2004). Age-related impairment in executive functioning: Updating, inhibition, shifting, and access. Journal of clinical and experimental neuropsychology, 26(7), 874-890.

Fogelman, N., \& Canli, T. (2018). Early life stress and cortisol: a meta-analysis. Hormones and Behavior, 98, 63-76.

Garon, N., Bryson, S. E., \& Smith, I. M. (2008). Executive function in preschoolers: a review using an integrative framework. Psychological Bulletin, 134(1), 31.

Groh, A. M., \& Narayan, A. J. (2019). Infant attachment insecurity and baseline physiological activity and physiological reactivity to interpersonal stress: A meta-analytic review. Child Development, 90(3), 679-693.

Hatch, S. L., \& Dohrenwend, B. P. (2007). Distribution of traumatic and other stressful life events by race/ethnicity, gender, SES and age: A review of the research. American Journal of Community Psychology, 40(3-4), 313-332.

Hayes, A. F. (2017). Introduction to mediation, moderation, and conditional process analysis: A regression-based approach. New York: Guilford Publications.

Hsieh, C. C., \& Pugh, M. D. (1993). Poverty, income inequality, and violent crime: a meta-analysis of recent aggregate data studies. Criminal Justice Review, 18(2), 182-202.

Iceland, J., \& Hernandez, E. (2017). Understanding trends in concentrated poverty: 1980-2014. Social Science Research, 62, 75-95.

Juhász, D. (2018). A verbális munkamemória fejlôdésének vizsgálata 5 éves kortól 85 éves korig. Iskolakultúra, 28(12), 35-53.

Kraag, G., Zeegers, M. P., Kok, G., Hosman, C., \& Abu-Saad, H. H. (2006). School programs targeting stress management in children and adolescents: A meta-analysis. Journal of School Psychology, 44(6), 449-472.

Kvestad, I., Hysing, M., Shrestha, M., Ulak, M., Thorne-Lyman, A. L., Henjum, S., \& Shrestha, P. S. (2017). Vitamin B-12 status in infancy is positively associated with development and cognitive functioning 5 y later in Nepalese children. The American Journal of Clinical Nutrition, 105(5), 1122-1131.

Lawson, G. M., Hook, C. J., \& Farah, M. J. (2018). A meta-analysis of the relationship between socioeconomic status and executive function performance among children. Developmental Science, 21(2), e12529.

Leventhal, T. (2018). Neighborhood Context and Children's Development: When Do Neighborhoods Matter Most? Child Development Perspectives, 12(4), 258-263. 
Lezak, M. D. (1982). The problem of assessing executive functions. International Journal of Psychology, 17(1-4), 281-297.

Lozoff, B. (2007). Iron deficiency and child development. Food and Nutrition Bulletin, 28(4, suppl4), S560-S571.

Lupien, S. J., King, S., Meaney, M. J., \& McEwen, B. S. (2001). Can poverty get under your skin? Basal cortisol levels and cognitive function in children from low and high socioeconomic status. Development and Psychopathology, 13(3), 653-676.

Lynam, D. R., Caspi, A., Moffit, T. E., Wikström, P. O., Loeber, R., \& Novak, S. (2000). The interaction between impulsivity and neighborhood context on offending: the effects of impulsivity are stronger in poorer neighborhoods. Journal of Abnormal Psychology, 109(4), 563.

Marshall, K., Teo, L., Shanahan, C., Legette, L., \& Mitmesser, S. H. (2020). Inadequate calcium and vitamin $\mathrm{D}$ intake and osteoporosis risk in older Americans living in poverty with food insecurities. PloS One, 15(7), e0235042.

McEwen, B. S. (2019). What is the confusion with cortisol? Chronic Stress, 3, 2470547019833647.

Mills-Koonce, W. R., Willoughby, M. T., Garrett-Peters, P., Wagner, N., Vernon-Feagans, L., \& INVESTIGATORS, T. F. L. P. K. (2016). The interplay among socioeconomic status, household chaos, and parenting in the prediction of child conduct problems and callous-unemotional behaviors. Development and Psychopathology, 28(3), 757.

Moffitt, T. E., Arseneault, L., Belsky, D., Dickson, N., Hancox, R. J., Harrington, H., \& Caspi, A. (2011). A gradient of childhood self-control predicts health, wealth, and public safety. Proceedings of the national Academy of Sciences, 108(7), 2693-2698.

D. Molnár, É. (2017). Erôfeszítés alapú kontroll és végrehajtó funkciók az önszabályozásban. Magyar Pszichológiai Szemle, 72(4), 533-547.

Morgan, P. L., Farkas, G., Hillemeier, M. M., \& Maczuga, S. (2012). Are minority children disproportionately represented in early intervention and early childhood special education? Educational Researcher, 41(9), 339-351.

Nelson, J. M., Sheffield, T. D., Chevalier, N., Clark, C. A. C., \& Espy, K. A. (2013). Psychobiology of executive function in early development. Integrating Measurement, Neurodevelopmental and Transitional Research. Washington DC: American Psychological Association.

Ngoma, C., \& Mayimbo, S. (2017). The negative impact of poverty on the health of women and children. Annals of Medical and Health Sciences Research, 7(6), 442-446.

Owens, A., \& Candipan, J. (2019). Social and spatial inequalities of educational opportunity: A portrait of schools serving high-and low-income neighbourhoods in US metropolitan areas. Urban Studies, 56(15), 3178-3197.

Peres, K. (2013). Corsi test. Creative Commons Attribution-ShareAlike 3.0 Unported Licens. Letöltve: 2018. 08. 27-én: https://docs.google.com/document/d/1SbdXT_ zcwGaK5TSFxnYSccxcVWIcoCpair9Xf9FeFRM/edit?usp=sharing

Piccolo, L. D. R., Sbicigo, J. B., Grassi-Oliveira, R., \& Fumagalli de Salles, J. (2014). Do socioeconomic status and stress reactivity really impact neurocognitive performance? Psychology \& Neuroscience, 7(4), 567.

Santiago, C. D., Wadsworth, M. E., \& Stump, J. (2011). Socioeconomic status, neighborhood disadvantage, and poverty-related stress: Prospective effects on psychological syndromes among diverse low-income families. Journal of Economic Psychology, 32(2), 218-230.

Sarsour, K., Sheridan, M., Jutte, D., Nuru-Jeter, A., Hinshaw, S., \& Boyce, W. T. (2011). Family socioeconomic status and child executive functions: The roles of language, home environment, and single parenthood. Journal of the International Neuropsychological Society: JINS, 17(1), 120.

St. John, A. M., \& Tarullo, A. R. (2020). Neighbourhood chaos moderates the association of socioeconomic status and child executive functioning. Infant and Child Development, 29(1), e2153. 
Stalder, T., Steudte-Schmiedgen, S., Alexander, N., Klucken, T., Vater, A., Wichmann, S., et al. (2017). Stress-related and basic determinants of hair cortisol in humans: A meta-analysis. Psychoneuroendocrinology, 77, 261-274.

Táncos, T., Janacsek, K., \& Németh, D. (2014). A munkamemória és végrehajtó funkciók kapcsolata az iskolai teljesítménnyel. Alkalmazott pszichológia, 14(2), 55-75.

Tomkins, A. (2001). Vitamin and mineral nutrition for the health and development of the children of Europe. Public Health Nutrition, 4(1a), 91-99.

Van IJzendoorn, M. H., Bakermans-Kranenburg, M. J., Coughlan, B., \& Reijman, S. (2020). Annual Research Review: Umbrella synthesis of meta-analyses on child maltreatment antecedents and interventions: differential susceptibility perspective on risk and resilience. Journal of Child Psychology and Psychiatry, 61(3), 272-290.

Venegas-Aviles, Y., Rodríguez-Ramírez, S., Monterrubio-Flores, E., \& García-Guerra, A. (2020). Sociodemographic factors associated with low intake of bioavailable iron in preschoolers: National Health and Nutrition Survey 2012, Mexico. Nutrition Journal, 19(1), 1-10.

White, L. S. (2012). Reducing stress in school-age girls through mindful yoga. Journal of Pediatric Health Care, 26(1), 45-56.

Wiebe, S. A., Sheffield, T. D., \& Espy, K. A. (2012). Separating the fish from the sharks: A longitudinal study of preschool response inhibition. Child Development, 83(4), 1245-1261.

World Health Organization (2020). UNICEF/WHO/The World Bank Group joint child malnutrition estimates: levels and trends in child malnutrition: key findings of the 2020 edition.

Wright, C. E., \& Steptoe, A. (2005). Subjective socioeconomic position, gender and cortisol responses to waking in an elderly population. Psychoneuroendocrinology, 30(6), 582-590.

Yoshikawa, H., Aber, J. L., \& Beardslee, W. R. (2012). The effects of poverty on the mental, emotional, and behavioral health of children and youth: implications for prevention. American Psychologist, 67(4), 272.

Zenner, C., Herrnleben-Kurz, S., \& Walach, H. (2014). Mindfulness-based interventions in schools - a systematic review and meta-analysis. Frontiers in Psychology, 5, 603.

Zhang, Y., Liu, X., Chen, J., Wang, R., Piao, J., Yang, X., \& Yang, L. (2017). Vitamin A nutritional status of Chinese rural children and adolescents in 2010-2012. Wei sheng yan jiu = Journal of Hygiene Research, 46(3), 345-349.

\title{
THE ROLE OF STRESS IN THE RELATIONSHIP BETWEEN SOCIOECONOMIC STATUS AND EXECUTIVE FUNCTIONS IN CHILDHOOD
}

\author{
KASSAI, RÉKA - FUTÓ, JUDIT - TAKACS, ZSOFIA K.
}

Background: Socioeconomically disadvantaged children lag behind in several areas of life, including the development of cognitive skills like executive functions, as compared to children living in higher social classes. It can be assumed that one of the underlying mechanisms behind this phenomenon is that these children are exposed to an increased amount of adverse stress throughout their lives. The aim of the present study was to examine the relationship between the components of socioeconomic status and executive functions in a Hungarian sample of preschool children, and the role of cortisol hormone levels (as an indicator of stress) in this regard.

Methods: We recruited a socioeconomically diverse sample of children from four different preschools. The analyses reported in the present study were performed based on data from 76 participants ( 45 male, 31 female, age range 52-83 months, mean age 70,85 months). Information regarding the socioeconomic status was collected from parents by questionnaires, children's executive functions were measured by computerized 
neuropsychological tests (Corsi Block, Go/No-Go, Hearts and Flowers), and their stress level was assessed by cortisol hormone levels from saliva samples (morning sampling, measured by ELISA method).

Results: Our results are in line with previous findings showing that it is only parental education that has a significant relationship with the executive functions of children, while family income does not. In addition, cortisol hormone levels were found to partially mediate the relationship between parental educational level and children's executive function capacities.

Conclusions: We can conclude that increased stress is one of the mechanisms through which socioeconomic status influences children's cognitive skills, but other factors may also be determinants.

Keywords: socioeconomical status, cortisol, executive functions, preschoolers

\section{MELLÉKLET}

Kérjük, jelölje az Önök háztartásának nettó havijövedelmét!

20.000 HUF-nál kevesebb

20.000 és 49.999 HUF között

50.000 és 99.999 HUF között

100.000 és 199.999 HUF között

200.000 és 299.999 HUF között

300.000 és 399.999 HUF között
400.000 és 499.999 HUF között 500.000 és 599.999 HUF között 600.000 és 699.999 HUF között 700.000 és 799.999 HUF között 800.000 és 999.999 HUF között 1.000.000 HUF-nál több

Alább kérjük, hogy a gyermekkel legtöbb idốt töltố gondviselók adatait jelölje X-szel / írja be:

\begin{tabular}{|l|l|l|l|}
\hline & Gondviselö 1 & Gondviselö 2 & Gondviselő 3 \\
\hline $\begin{array}{l}\text { Ki ó (pl. édesanya, } \\
\text { édesapa, más) }\end{array}$ & & & \\
\hline Életkora: & & & \\
\hline $\begin{array}{l}\text { Legmagasabb iskolai } \\
\text { végzettsége: }\end{array}$ & & & \\
\hline kevesebb mint 8 osztály: & $\ldots \ldots \ldots$...osztály & $\ldots \ldots \ldots$. . & \\
\hline általánóly & $\ldots \ldots \ldots$ osztály \\
\hline középiskola & & & \\
\hline szakképzés & & & \\
\hline fốiskola & & & \\
\hline egyetem & & & \\
\hline PhD: & & & \\
\hline egyéb: & & & \\
\hline
\end{tabular}

A cikk a Creative Commons Attribution 4.0 International License (https://creativecommons. org/licenses/by/4.0/) feltételei szerint publikált Open Access közlemény, melynek szellemében a cikk bármilyen médiumban szabadon felhasználható, megosztható és újraközölhetô, feltéve, hogy az eredeti szerzô és a közlés helye, illetve a CC License linkje és az esetlegesen végrehajtott módosítások feltüntetésre kerülnek. (SID_1) 